ELKOM, Vol.12, No.2, Desember 2019, pp. 10 - 14

p-ISSN : 1907-0012 (print)

e-ISSN : 2714-5417 (online)

http://ejurnal.stekom.ac.id/index.php/home

- page 10

\title{
Pemanfaatan Website Sebagai Sistem Informasi Untuk Manajemen Persediaan Barang Pada Toko X
}

\author{
Febryantahanuji ${ }^{1}$, Triyani ${ }^{2}$, Arsito Ari Kuncoro ${ }^{3}$ \\ ${ }^{1}$ Progdi Manajemen Informatika STEKOM Semarang \\ febryan@stekom.ac.id \\ ${ }^{2}$ Progdi Komputerisasi Akuntansi STEKOM Semarang \\ triyani@gmail.com \\ ${ }^{3}$ Progdi Sistem Komputer STEKOM Semarang \\ arsito@stekom.ac.id \\ Jl. Majapahit 605, Semarang, telp/fax : 024-6717201-02
}

\section{ARTICLE INFO}

Article history:

Received 30 November 2019

Received in revised form 2 Desember 2019

Accepted 10 Desember 2019

Available online 12 Desember 2019

\section{ABSTRACT}

In today's industry competition the use of a technology is very important, including in inventory management. This system is used to enter inventory data into the database so that there are no errors in the report. So that in it often occurs stock report errors in the availability of goods that result in data not being updated, the system that will be created by the author is a system of inventory information that is useful to overcome these problems. This system is also equipped with reports on incoming and outgoing goods data reports, minimum and maximum stock reports, and Web-based stock data reports. With this inventory information system, it is expected to be able to help the existing problems, facilitate data collection, the system built can provide access rights for each user, as well as facilitate the preparation of reports so that the Program is able to handle existing problems.

Keywords: Informatics, Management, Information, Systems

\section{PENDAHULUAN}

Manajemen saat ini perlu didukung dengan adanya teknologi informasi yang mempercepat pendataan barang. Proses stok barang yang dilakukan hanya dengan cara manual dapat memerlukan banyak waktu dan tenaga. Lain daripada menyusun data-data juga akan mengalami keterlambatan dengan dilakukanya cara mengelola stok barang yang berupa manual. Sehingga laporan-laporan yang dibutuhkan tidak dapat langsung disediakan karena masih menerapkan sistem manual belum terkomputerisasi. Untuk mengatasi masalah ini maka penulis membuat Sistem Informasi Manajemen untut Persedian Barang dengan berbasis Web, dengan adanya sistem ini pimpinan dapat langsung mengetahui jumlah stok hanya melalui web dan pimpinan dapat mengecek laporan secara cepat karena sudah tersedia laporan setiap periodenya. Adapun studi kasus dalam penelitian ini adalah sebuah toko persediaan bahan makanan. Sistem informasi berbasis Web yang berguna sebagai mempercepat pekerjaan dalam segi waktu dan tempat, mengurangi resiko mengenai jumlah stok yang terlalu banyak dan barang yang terlalu sedikit, akibatnya berdampak pada stok tersebut [1]. Adapun penelitian yang menyatakan bahwa dengan adanya system infromasi persedian barang berbasis website dapat menghasilkan laporan yang akuran dan efektif [2].

\section{TINJAUAN PUSTAKA}

\section{A. Kajian Ilmiah}

Received November 23, 2019; Revised November 29, 2019; Accepted Desember 12, 2019 
Dalam jurnal yang berjudul tentang Sistem Informasi Persediaan Barang Berbasis Web di PT. Putera Agung Setia dengan menggunakan bahasa pemprograman PHP versi 5.2.6 serta menggunakan sistem basis data MySQL dengan dukungan Software Dreamweaver yang memiliki media penyimpanan terpusat dalam database server. Sistem ini dapat menampilkan data dalam proses pemesanan [3]. Adapun jurnal penelitian dalam pemanfaatan website untuk promosi sebuah madrah, dimana dengan menggunakan website dapat mempercepat promosi karena tidak terbatas ruang dan waktu dan dapat meningkatkan peserta didik sesuai harapan instansi [4]. Dalam kajian penelitian penulis dapat disimpulkan bahwa penggunaan website dalam mengelola persedian barang maupun promosi sangat membantu sebuah instansi, dalam penelitian yang dilakukan oleh penulis, system persedian barang menggunakan website dilengkapi dengan transaksi barang masuk dan keluar, menggunakan metode R\&D yang dimana memliki validasi tinggi.

\section{B. Diskripsi Teoritik}

1. Sistem

Sistem adalah bagian yang sangat dekat atau selalu melekat dan selalu ada di dalam kehidupan meski kita sadari maupun tidak. Kita sendiri manusia dapat disebut sistem khususnya sistem manusia, lingkungan tempat tinggal kita bisa disebut sistem lingkungan, kampus juga bisa disebut sistem universitas dan masih banyak contoh sistem yang bisa kita cari disekitar kita [5].

\section{Website}

Website atau biasa disebut tempat online yang mempunyai arti diantara halaman yang dipergunakan sebagai penampil teks informasi, animasi bergerak atau diam serta dibentuk dalam rangkaian bangun yang saling terkait, masing-masing cara penghubunganya menggunakan jaringan-jaringan halaman [6].

\section{METODE PENGEMBANGAN}

Penulis menggunakan 6 dari 10 langkah metode penelitian dan pengembangan (Research and Development). Model pengembangan sistem yang digunakan adalah prototyping dan menghasilkan sebuah produk dalam bentuk prototype dan menghasilkabn suatu produk berbentuk prototype. Model pengembangan [7] tersebut mempunyai langkah-langkah sebagai berikut:

1. Penelitian dan pengumpulan data (Research and informing collecting)

2. Perencanaan penelitian (Planning)

3. Pengembangan produk awal (Develop preliminary form of Product)

4. Uji lapangan terbatas (Preliminary field testing)

5. Revisi hasil uji (Main product revision)

6. Uji lapangan lebih luas (Main field testing)

7. Revisi hasil uji lapangan luas (Operational product revision)

8. Uji kelayakan (Operational field testing)

9. Revisi hasil uji kelayakan (Final product revision)

10. Diseminasi dan sosialisasi produk akhir (Dissemination and Implementation)

\section{HASIL DAN PEMBAHASAN}

Sistem baru yang diusulkan adalah mengenai informasi dan pengelolaan data mulai dari input dan proses output. Sistem yang akan dibentuk adalah Sistem Informasi Persediaan Barang Berbasis Website.

\section{Form Login}

Form ini digunakan untuk masuk kedalam sistem. Seorang pengguna harus melakukan uji username dan password, apabila username dan password tidak terdaftar maka tidak bisa melakukan akses kedalam sistem.

\section{Form Administrator}

Form ini akan menampilkan dan mengatur hak akses semua admin yang dapat login ke sistem.

\section{Form Data Supplier}

Form ini mencatat data supplier 


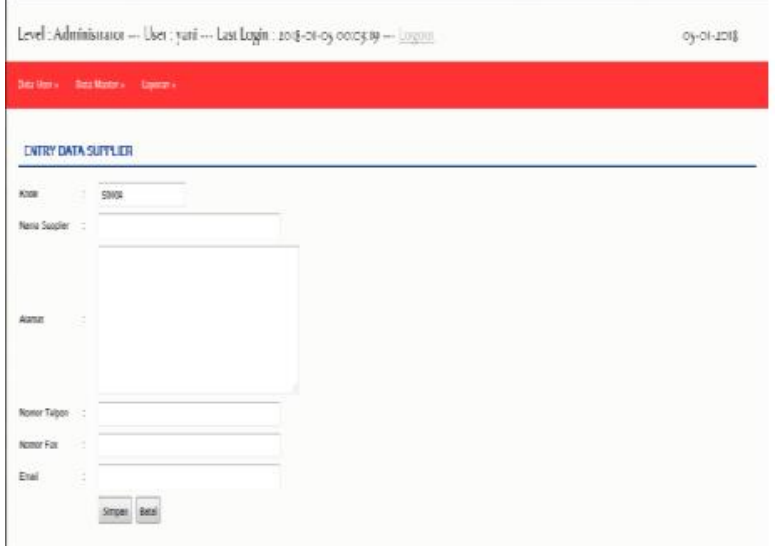

Gambar 1. Tampilan Form Data Supplier

4. Form Data Barang

Form ini mencatat data barang, meliputi harga jual dan harga beli.

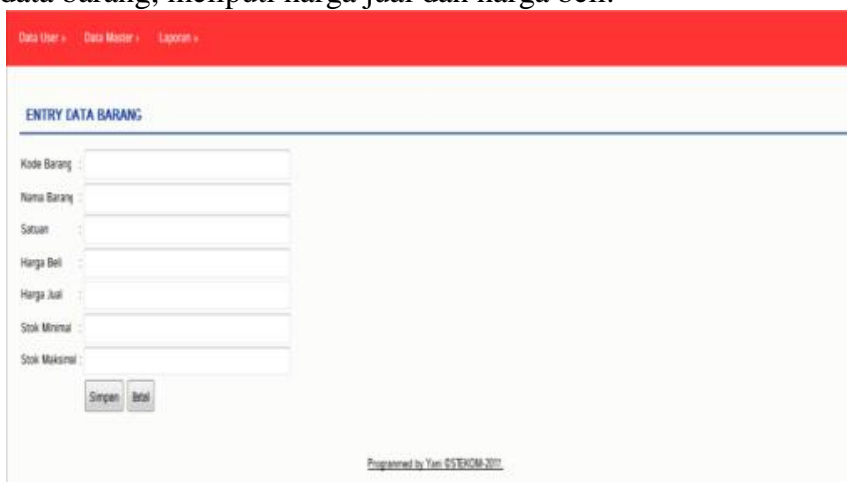

Gambar 2. Tampilan Form Data Barang

5. Laporan Data Stok

Pada halaman ini akan menampilkan laporan data stok barang yang ada.

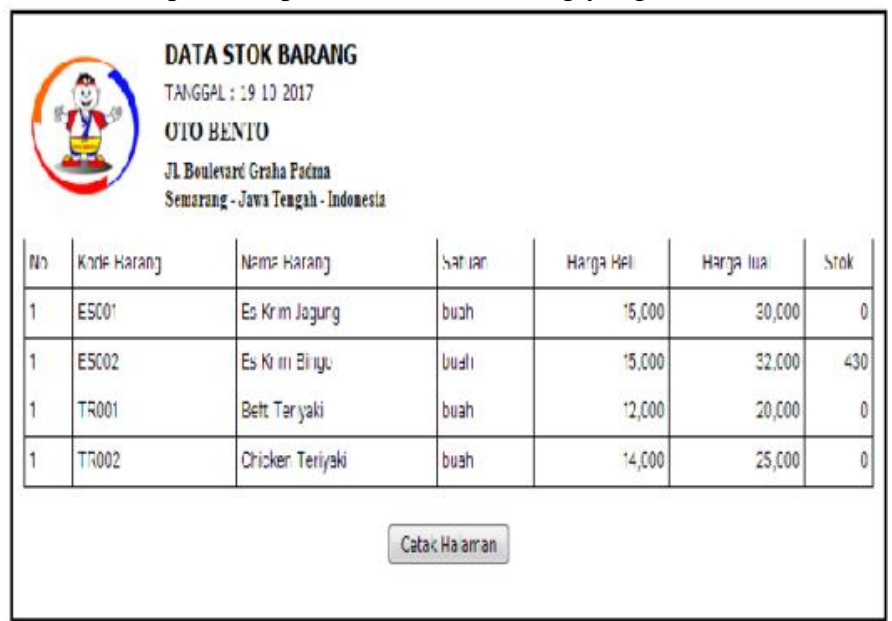

Gambar 3. Tampilan Laporan Data Stok

6. Form data masuk bag.Gudang

Pada halaman ini akan menampilkan data barang masuk pada bagian Gudang. Terdapat kolom nomor ELKOM Vol. 12, No. 2, Desember 2019 : $10-14$ 
faktur tanggal masuk, nama supplier, kode barang serta jumlah pengiriman.

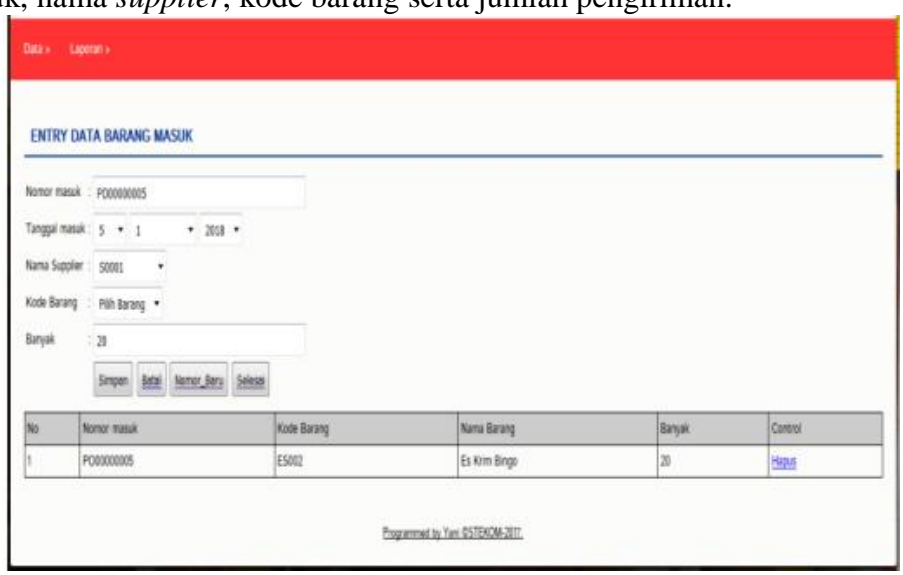

Gambar 4. Tampilan halaman data barang masuk bag.gudang

7. Form data keluar bag.Gudang

Pada halaman ini akan menampilkan data barang masuk pada bagian Gudang. Terdapat kolom nomor faktur tanggal masuk, nama suplier, kode barang serta jumlah pengiriman.

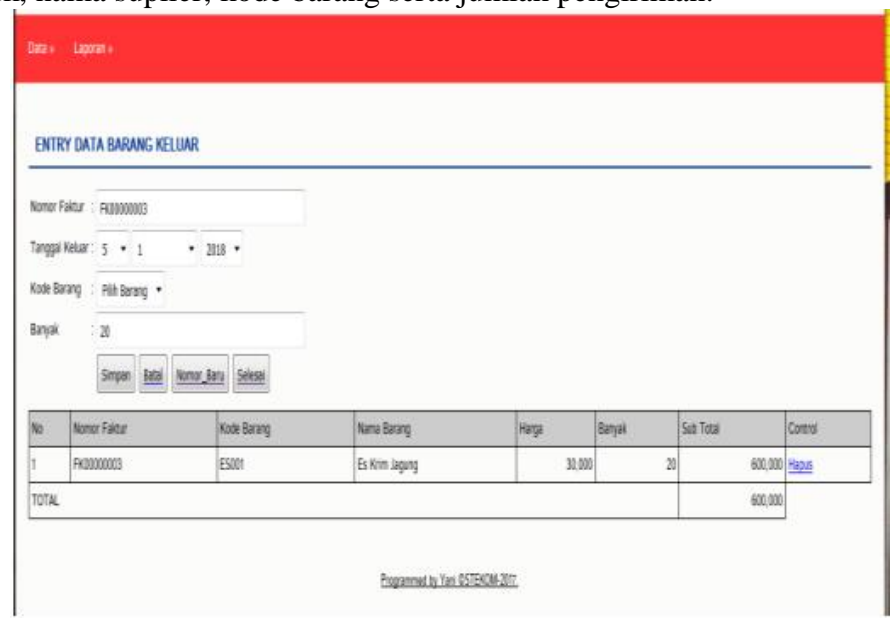

Gambar 5. Tampilan halaman data barang keluar bag.gudang

\section{Data Kartu Stok}

Pada halaman ini tampilan stok barang saat ini, yang terdapat beberapa kolom yaitu kolom tanggal, keterangan ini dapat disebut juga nama suplier, jumlah masuk dan jumlah keluar atau retur serta data stok. Tombol cetak halaman untuk proses print kartu stok. 


\begin{tabular}{|c|c|c|c|c|c|c|}
\hline & $\begin{array}{l}\text { KARTL } \\
\text { TANGGAL } \\
\text { OTO BE } \\
\text { J. Boulen: } \\
\text { Semarang }\end{array}$ & & & & & \\
\hline \multicolumn{7}{|c|}{ Kode Barang : E5002 Nama Barang, Es Krim Bingo } \\
\hline No & Tanggal & Keterangan & Masuk & & & Stok \\
\hline 1 & 20 September 2017 & Tambak Sari & 5 & & 0 & 50 \\
\hline 2 & 22 September 2017 & Tambak Sari & 40 & & 0 & 430 \\
\hline 3 & 19 Oktober 2017 & Aneka Farm & 4 & & 0 & 470 \\
\hline 4 & 20 September 2017 & & ( & 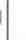 & 20 & 30 \\
\hline & & Cetak Halaman & & & & \\
\hline
\end{tabular}

Gambar 6. Tampilan halaman kartu stok

\section{KESIMPULAN}

Berdasarkan hasil penelitian, perancangan, dan pengujian terhadap pemanafaatan website sistem informasi manajemen persediaan barang dapat ditarik kesimpulan sebagai berikut:

1. Pembuatan aplikasi persediaan barang berbasis web sudah dapat mengurangi permasalahan yang ada, antara lain:

a) Mempermudah pendataan jumlah stok barang yang ada di gudang.

b) Memudahkan para karyawan untuk mencari barang sesuai dengan kriteria yang diinginkan.

2. Sistem yang dibangun dapat memberikan hak akses pada masingmasing user.

3. Sistem informasi akuntansi persediaan barang ini telah dilengkapi dengan berbagai fitur tambahan bagi masing-masing pengguna/user yang bersangkutan dalam hal pertanggungjawaban setiap laporan. Dengan adanya sistem informasi persediaan akan mudah mengontrol stok barang karena dilengkapi dengan aplikasi stok maksimal dan minimal.

\section{DAFTAR PUSTAKA}

[1] Sutarman, Pengantar Teknologi Informasi. Jakarta: Bumi Aksara, 2012.

[2] Rini Rubhiyanti; Febryantahanuji, "Penerapan Metode Economic Order Quantity (Eoq) Untuk Persediaan Barang Berbasis Web," JAE, vol. 3, pp. 12-23, 2018.

[3] N. H. Cahya, "Pengembangan Sistem Informasi Persediaan barang Berbasis Web Di PT. Putera Agung Setia," SEMNASIF, 2012.

[4] Febryantahanuji, "Pemanfaatan Website Sebagai Media Promosi Dan Meningkatkan Peserta Didik Pada (Ma) Madrasah Aliyah Ibrohimiyyah Demak,” J. NUSAMBA, vol. 2, pp. 142-148, 2017.

[5] Taufiq, Sistem Informasi Manajemen Konsep Dasar, Analisa dan Metode Pengembangan. Yogyakarta: Graha Ilmu, 2013.

[6] R. Hidayat, Cara Praktis Membangun Website Gratis: Pengertian Website. Jakarta: Elek Media Komputindo Kompas Gramedia, 2010.

[7] G. D. Borg Walter R, Educational Research: An Introduction. 1983.

ELKOM Vol. 12, No. 2, Desember 2019 : $10-14$ 